\title{
IMPLEMENTASI E-GOVERNMENT UNTUK PELAYANAN PUBLIK DI PROVINSI BANTEN
}

\section{THE IMPLEMENTATION OF E-GOVERNMENT FOR PUBLIC SERVICES IN BANTEN PROVINCE}

\author{
Yana Suharyana \\ Badan Perencanaan Pembangunan Daerah (Bappeda) Provinsi Banten \\ J1. Syeh Nawawi Albantani KP3B Palima Curug Kota Serang \\ tlp. (0254) 267053 fax. (0254) 267052 \\ E-mail:ysuharyana@yahoo.com
}

\begin{abstract}
ABSTRAK
Implementasi e-government untuk memberikan pelayanan kepada publik sangat diharapkan demi terjalinnya komunikasi antara pemerintah dan masyarakat. Namun demikian masih terjadi ketidakseimbangan antara informasi yang diharapkan masyarakat dengan informasi yang disajikan oleh pemerintah terutama informasi melalui media elektronik. Penelitian ini bertujuan untuk menganalisis implementasi e-government di Pemerintah Provinsi Banten didasarkan kebijakan tentang pelayanan publik dan evaluasi kebijakan e-government dengan metodologi penelitian kualitatif. Hal ini dilakukan dengan cara membandingkan amanat Inpres No. 3 tahun 2003 tentang pengembangan pelaksanaan e-government, dengan konten pelayanan publik pada situs web bantenprov.go.id. Hasil yang ditemukan dari penelitian ini adalah adanya pengelolaan sistem informasi yang belum terintegrasi dengan unit kerja lainnya, selain itu masih adanya sistem layanan informasi yang dibutuhkan masyarakat tetapi masih belum tersedia didalam sistem tersebut. Untuk meningkatkan pelaksanaan e-government tersebut perlu diberikan rekomendasi yang mendukung upaya peningkatan dalam pelayanan e-government tersebut melalui penyediaan regulasi atau kebijakan pengelolaan e-government, penyempurnaan pengelolaan perangkat lunak (software), perangkat keras (hardware), sumber daya manusia (brainware).
\end{abstract}

Kata kunci : e-government, pelayanan publik, Provinsi Banten

\section{ABSTRACT}

To establish communication between the government and the public about the available services, e-government needs to be implemented. There is still, however, imbalance between the information expected by the society and the information presented by the government, especially information through electronic media. This study seeks to analyse the implementation of e-government in the Banten Province based on policies about public services and the evaluation of e-government policies in the province. This research employs a qualitative method, and data is collected by comparing the mandate of Presidential Decree number 3 of 2003 about national strategy and policy for the development of e-government, and the content of public services available on the bantenprov.go.id website. The study found that the information management system is not yet integrated with other work units, in addition to the lack of information needed 
by the community about public services. The study further recommended the provision of regulations and policy management of e-government, alongside with improving the management of software, hardware, and brain ware (Human Resources) to enhance the implementation of egovernment in Banten Province.

Keywords: e-government, province of Banten, public services.

\section{PENDAHULUAN}

\section{E-Goverment (electronic govern-ment)} adalah suatu pemanfaatan teknologi informasi baik internet maupun non-internet, untuk menyediakan pelayanan yang lebih nyaman dan efisien terhadap warga dan organisasi atas informasi dan pelayanan pemerintah (priyatno, 2009). Implementasi e-governmnet untuk meningkatkan komunikasi antara pemerintah dan masyarakat merupakan kebutuhan yang sangat mendesak sebagaimana tertuang dalam Undang-undang no. 14 tahun 2008 tentang keterbukaan informasi publik. Untuk menjawab tuntutan tersebut pemerintah Provinsi Banten telah membuat website bantenprov.go.id, selain itu pemerintah Provinsi Banten juga memayuni tentang keterbukaan informasi ini melalui peraturan Gubernur Banten no. 16 tahun 2011 tentang pedoman pelayanan informasi publik dan dokumentasi di lingkungan Provinsi Banten. Peraturan Gubernur tersebut dimaksudkan sebagai upaya peningkatan layanan informasi kepada masyarakat.
Kemajuan teknologi informasi sekarang ini secara perlahan mengubah pola interaksi dan komunikasi yang modern baik antar masyarakat maupun pemerintah dengan masyarakat, hal ini menjadi tugas aparatur pemerintah untuk bisa menyesuaikan perkembangan zaman melalui penyediaan informasi dan pola komunikasi yang lebik baik, efektif dan efisien. Namun didalam perjalanannya, e-government pada Pemerintah Provinsi Banten masih memiliki banyak kekurangan terutama konten yang berhubungan dengan informasi layanan publik, sebagai contoh kekurangan yang ada di dalam website bantenprov.go.id adalah belum adanya informasi menyangkut data perencanaan mulai dari perencanaan jangka pendek sampai dengan jangka panjang pada tahun berjalan, belum adanya informasi keuangan terutama pelaksanaan anggaran tahun berjalan, belum lengkapnya konten yang menyediakan informasi layanan masyarakat bidang kesehatan misalnya pendaftaran pasien di RSUD Banten, bidang pendapatan daerah misalnya pembayaran 
pajak kendaraan bermotor dan beberapa layanan lainnya yang berbasis online. Dalam implementasi e-government untuk pelayanan kepada masyarakat, kendala yang sering dihadapi tidak hanya menyangkut ketersediaan perangkat keras, perangkat lunak atau biaya operasional, regulasi atau kebijakan operasional layanan informasi publik online-nya saja tetapi yang tidak kalah pentingnya adalah menyangkut komitmen bersama dalam persoalan manajerial (Dwiyanto, 2006). Salah satu faktor yang mempengaruhi keberhasilan suatu program adalah komitmen pimpinan serta kompetensi Sumber daya manusia yang mengelolanya (Faizah dkk, 2009). Penelitian ini sudah beberapa kali dilakukan oleh peneliti diantaranya : analisis pengembangan e-government di Kota Semarang (Alifian Adi Prasetyo dkk, 2009, hal 10), framework strategi implementasi e-government (Suhono Harso Supangkat, 2006 hal 37), E-government : studi pendahuluan di kabupaten Sragen (Ikhsan Darmawan, 2011, hal 74) dari ketiga tulisan diatas lingkupnya sudah baik dalam membahas strategi pengembangan $e$ government namun demikian secara khusus tidak membahas pelaksanaan e-governmnet berdasarkan kebutuhan sumber daya teknologi informasinya maupun regulasinya. Pada tulisan lain : tantangan dan hambatan dalam implementasi e-government di Indonesia (Edwi Arief Sosiawan, 2008, hal 108) pada tulisan ini sudah membahas berkaitan dengan Sumber Daya Manusia (SDM), infrastruktur, dan regulasinya tetapi belum membahas secara detail hal-hal apa saja harus di evaluasi terkait ketiga faktor tersebut. Maka tulisan ini mengisi kekosongan tersebut dengan membahasn faktor apa saja yang harus menjadi fokus perhatian baik dari aspek sumber daya teknologi informasi, Sumber Daya Manusia (SDM), maupun regulasi pelaksanaan e-government tersebut yang sesuai dengan aturan pengembangan e-government.

Penelitian ini bertujuan untuk melihat pelaksanaan e-government di Provinsi Banten baik dari sisi sumber daya teknologi informasi dan regulasi yang menjadi dasar pelaksanaan e-government di Provinsi Banten .

\section{METODE PENELITIAN}

Penelitian ini menggunakan metodologi kualitatif melalui wawancara dengan informan sesuai tugas pokoknya dalam mengelola informasi publik melalui wawancara dan pengamatan langsung dengan cara mengidentifikasi, menilai dan menganalisis implementasi e-government dalam rangka peningkatan kinerja pelayanan 
publik melalui situs bantenprov.go.id yang didasarkan pada Instruksi Presiden Nomor 3 Tahun 2003 tentang Kebijakan dan Strategi Nasional Pengembangan E-Government.

\section{HASIL DAN PEMBAHASAN}

\section{PEMBAHASAN}

E-government untuk pelayanan publik bertujuan untuk memberikan pelayanan publik secara penuh kepada masyarakat dalam bentuk penyampaian informasi meliputi penyampaian informasi program kerja, visi misi, pelayanan publik, hingga hubungan ke setiap Satuan Kerja Perangkat Daerah (SKPD) termasuk pada pihak eksternal (mustafid dkk, 2014). Pelayanan publik yang berkualitas merupakan amanat dari UU RI Nomor 25 tahun 2009 tentang Pelayanan Publik yang didalamnya mengatur prinsip-prinsip pemerintahan yang baik agar fungsi-fungsi pemerintahan dalam melaksanakan pelayanan publik dapat berjalan efektif.

Pelayanan publik berbasis e-government dapat mempermudah masyarakat untuk mengakses berbagai layanan tanpa harus datang langsung ke kantor pemerintahan (Junaidi, 2011). Kelengkapan dan keterbukaan informasi pada e-government yang dapat diakses akan mendorong terciptanya good governance dalam pemerintahan melalui peningkatan transparansi dan akuntabilitas pada lembagalembaga layanan publik. E-government juga diharapkan dapat meningkatkan produktivitas dan efisiensi birokrasi, sehingga dapat meningkatkan kreatifitas dan inovasi, baik dari pihak penyelenggara pelayanan publik ataupun bagi masyarakat. Berdasarkan Inpres Nomor 3 Tahun 2003 tentang Kebijakan dan Strategi Nasional Pengembangan E-Government, pemerintah harus mampu memenuhi dua modalitas tuntutan masyarakat yang berbeda namun berkaitan erat, yaitu :

1. Masyarakat menuntut pelayanan publik yang memenuhi kepentingan masyarakat luas di seluruh wilayah Indonesia, dapat diandalkan dan terpercaya, serta mudah dijangkau secara interaktif;

2. Masyarakat menginginkan agar aspirasi mereka didengar, sehingga pemerintah harus memfasilitasi partisipasi dan dialog publik di dalam perumusan kebijakan negara.

Dalam memanfaatkan kemajuan teknologi informasi dan komunikasi, maka pemerintah daerah dituntut secara otonom harus dapat melaksanakan proses transformasi dari penyajian informasi dan 
komunikasi yang konvensional menuju penyajian informasi dan komunikasi secara elektronik hal ini sesuai definisi dari Bank Dunia, e-government merupakan penggunaan teknologi informasi oleh pemerintah, yang memungkinkan pemerintah untuk mentransformasikan hubungan dengan masyarakat, dunia bisnis dan pihak yang berkepentingan. Sesuai dengan Inpres Nomor 3 Tahun 2003, pengembangan e-government diarahkan untuk mencapai empat tujuan, yaitu ;

1. Pembentukan jaringan informasi dan transaksi pelayanan publik yang memiliki kualitas dan lingkup yang dapat memuaskan masyarakat luas serta dapat terjangkau di seluruh wilayah Indonesia pada setiap saat tanpa dibatasi oleh sekat waktu dan biaya yang terjangkau oleh masyarakat.

2. Pembentukan hubungan interaktif dengan dunia usaha untuk meningkatkan perkembangan perekonomian nasional dan memperkuat kemampuan menghadapi perubahan dan persaingan perdagangan internasional.

3. Pembentukan mekanisme dan saluran komunikasi dengan lembaga-lembaga negara serta penyediaan fasilitas dia- log bagi masyarakat agar dapat berpartisipasi dalam perumusan kebijakan negara.

4. Pembentukan sistem manajemen dan proses kerja yang transparan dan efisien serta memperlancar transaksi dan layanan antar lembaga pemerintah dan pemerintah daerah otonom.

Beberapa faktor utama pada setiap dimensi yang menjadi kelemahan dalam implementasi e-government untuk pelayanan publik. Faktor utama tersebut menjadi perhatian dalam melakukan perbaikan atau penyempurnaan implementasi e-government yang bertujuan untuk peningkatan kinerja pelayanan publik diantaranya adalah sebagai berikut :

\section{Kebijakan}

Koordinasi kegiatan dan anggaran dalam pengembangan dan pemanfaatan teknologi informasi dan komunikasi (TIK) setiap OPD sangat berperan untuk melakukan perencanaan dan evaluasi atas efektifitas dan efisiensi anggaran TIK sebagaimana tujuan diselenggarakannya $e$ government. Standard Operating Procedure (SOP) pengadaan, perencanaan, pemanfaatan dan pengendalian hal yang dimaksud diatas tentunya harus didukung 
regulasi di tingkat daerah harus disediakan sebagai dasar pelaksanaannya. Penggunaan SOP pengadaan, perencanaan, pemanfaatan dan pengendalian terkait dengan pengembangan dan pengelolaan e-government akan mendorong keberhasilan dalam penyelenggaraan pengadaan dan pemanfaatan TIK agar setiap OPD dapat menyesuaikan dengan standar anggaran dan operasional yang telah ditentukan.

\section{Kelembagaan}

a) Organisasi fungsional. Organisasi ini hendaknya dipimpin langsung oleh kepala daerah dengan fungsi yang menentukan kebijakan dan anggaran pengembangan dan pemanfaatan TIK. Belum adanya organisasi fungsional seperti Dewan TIK daerah sebagaimana pengarahan dari Kementrian Komunikasi dan Informasi pada Peraturan Menteri Kominfo Nomor 41 Tahun 2007 (tentang Panduan Umum Tata Kelola Teknologi Informasi dan Komunikasi Nasional) beresiko banyak usulan kebijakan dari pejabat Eselon 3 tidak bisa menjangkau ke seluruh SKPD yang sebagian besar berada di Eselon II.

b) Lembaga khusus yang menangani teknologi informasi seharusnya memiliki sebuah lembaga khusus yang menangani TIK untuk pengelolaan $e$ government. Sehingga kewenangan pengelolaan TIK menjadi jelas, apakah pada Bagian Kominfo, Bagian PDE ataupun Bagian Humas. Keberadaan lembaga ini akan memberikan kontrol atas pengembangan dan pemanfaatan TIK, serta kontrol anggaran secara terintegrasi agar dapat dilaksanakan dengan baik, dan mampu menyediakan e-government yang efektif dan efisien

c) Tenaga teknis dalam bidang TIK. Adanya tenaga teknis programer, analis sistem dan teknisi jaringan yang cukup disertai dengan pelatihan berjenjang dapat meminimalkan kurang optimalnya layanan infrastruktur.

Implementasi e-government memerlukan sistem terintegrasi, sehingga data dapat diolah dalam sistem yang terintegrasi antara Organisasi Perangkat Daerah (OPD) yang satu dengan OPD yang lain. Resiko yang muncul atas kondisi data dengan sistem yang terintegrasi antara lain dapat menyebabkan kesulitan dalam pencarian data, kesulitan dalam pelaporan data, resiko dalam keamanan data, serta resiko dalam integritas data. 
Pengelolaan bandwidth. Pengelolaan bandwidth dilakukan secara terintegrasi, sehingga bandwidth yang tersedia dapat secara optimal yang dapat digunakan oleh setiap OPD sesuai dengan kebutuhan. Pengelolaan bandwidth secara tidak terintegrasi pada OPD beresiko pada penggunaan sumber daya TI dan kegiaatan pemanfaatan TIK tidak bisa terkontrol dengan baik. Perangkat akses, server dan storage. Perlu dibangun adanya data center yang sesuai dengan standar, sehingga kebutuhan perangkat akses, server dan storage dapat dikelola oleh OPD tertentu, misalnya pada Kominfo, PDE maupun Humas. Pengelolaan data center secara mandiri akan mereduksi kerawanan keamanan informasi.

\section{Evaluasi Implementasi E-Government Provinsi Banten}

Provinsi Banten merupakan provinsi pemekaran dari Provinsi Jawa Barat yang secara legal berdiri sejak tahun 2000. E-government di Pemerintah Provinsi Banten telah dioperasionalkan dengan situs www.bantenprov.go.id menggunakan sistem jaringan yang belum efektif terkoneksi antar OPD untuk melaksanakan tugas dan fungsi pelayanan publik. Pengembangan sistem $e$ government telah dilakukan melalui kegiatan sosialisasi dan penyeragaman konten website tipa OPD oleh dinas kominfo, namun sebagai gambaran awal bahwa pelaksanaan e-government di Provinsi Banten belum menggambarkan sebagai layanan publik sebagaimana terkandung dalam amanat Inpres Nomor 3 Tahun 2003. Pada kenyataannya memang sulit mengubah kebiasaan kerja manual ke sistem yang berbasis elektronik sesuai dengan tujuan dan fungsi e-government, transformasi proses kerja dari sistem secara manual seharusnya terjadi perubahan yang disesuaikan untuk memungkinkan berjalannya sistem elektronik secara efektif dan optimal. Halhal yang ditemukan pada proses implementasi e-governmnet di Provinsi Banten adalah sebagai berikut :

\section{Aspek Kebijakan}

Pada aspek kebijakan, di Provinsi Banten belum ada regulasi yang secara operasional mengatur informasi yang dikecualikan, pengelolaan sistem informasi apa saja yang harus disedikan sesuai tugas, pokok dan fungsi setiap OPD dalam memberikan pelayanan kepada masyarakat serta pelaksanaan fungsi pengawasan yang berkaitan pemberian reward dan punishment dalam proses pelaksanaan e-government dipemerintah Provinsi Banten. 


\section{Aspek Aplikasi :}

Berdasarkan hasil yang ditemukan halhal yang berkaitan dengan pengelolaan aspek aplikasi diantaranya sebagai berikut :

1. Secara umum isi konten website bantenprov.go.id menggambarkan komunikasi satu arah antara pemerintah dengan masyarakat.

2. Kurangnya informasi berkaitan dengan perencanaan program dan kegiatan pada lingkup Pemerintah Provinsi Banten yang meliputi rencana jangka pendek, menengah, dan jangka panjang.

3. Belum ada keseragaman konten pada isi website tiap OPD sehingga pencarian informasi tertentu sulit ditemukan misalnya pada konten yang harus di sediakan oleh setiap OPD.

4. Kurangnya informasi rincian belanja berdasarkan program-program yang ditangani Provinsi Banten terutama pada tahun berjalan.

5. Belum terintegrasinya informasi layanan publik antar OPD di lingkup Pemerintah Provinsi Banten yang disampaikan melalui situs web bantenprov.go.id sebagai media untuk mempublikasikan semua layanan yang ada di tiap OPD provinsi Banten.
6. Belum ada koneksi layanan dengan lembaga penyelenggaran negara lainnya yang menyediakan fasilitas layanan publik misalnya di wilayah kewenangan provinsi Banten terdapat beberapa kantor imigrasi yang tersebar di kab/kota tetapi pada konten layanan masyarakat di website bantenprov.go.id tidak memfasilitasi layanan yang dilakukan kantor imigrasi misalnya menu pendaftaran paspor online dsb.

Dari gambaran diatas menunjukan bahwa masih perlu perhatian dalam pengelolaan aplikasi serta upaya pengembangan untuk mentigerasikan aplikasi yang satu dengan yang lainnya, baik aplikasi layanan publik yang ada pada lingkup kewenangan Provinsi Banten maupun aplikasi yang disediakan oleh intansi vertikal yang memberikan pelayanan di wilayah Provinsi Banten. sehingga memudahkan masyarakat untuk mengaksesnya.

\section{Aspek Sumber Daya Manusia (SDM) /}

\section{Brainware}

Berdasarkan hasil wawancara ditemukan hal-hal yang berkaitan dengan pengelolaan Sumber Daya Manusia (SDM) 
diantaranya sebagai berikut :

1. Belum efektifnya pembinaan Sumber Daya Manusia (SDM) yang bertanggung jawab pada pengelolaan bidang teknologi informasi sebagai contoh masih terjadi perpindahan pegawai sehingga proses pengelolaan bidang teknologi informasi terganggu.

2. Sudah ada pertemuan berkala antara pengelola sistem informasi utama (misalnya kominfo) dengan pengelola sistem informasi pembantu (tiap OPD) tetapi belum membahas bagaimana upaya perbaikan konten layanan masyarakat.

3. Komitmen pimpinan dalam menjalankan konsep dan aturan pelaksanaan e-government di setiap OPD Provinsi Banten yang diatur oleh kebijakan yang berlaku dan wajib dilakukan oleh setiap perangkat daerah.

4. Masih terjadi double job (pekerjaan ganda) pegawai yang melaksanakan pengelolaan website dengan tugastugas administrasi lainnya sehingga proses pengelolaan tidak berjalan sebagaimana mestinya.

Dari situasi diatas menggambarkan ketidak-konsistenan pola pengelolaan serta komitmen sumber daya manusia dalam pelaksanaan aturan yang mendukung pelaksanaan e-government yang ideal.

\section{Aspek Perangkat Keras (Hardware)}

Berdasarkan hasil pengamatan dan wawancara dilapangan ditemukan hal-hal sebagai berikut :

1. Belum adanya keseragaman spesifikasi perangkat keras yang digunakan dalam menunjang pelaksanaan e-government terutama spesifikasi server dan perangat inti lainnya yang harus di sediakan. Misalnya spesifikasi komputer server.

2. Alokasi bandwidht di tiap OPD sebagai penunjang pelaksanaan e-government sering digunakan tidak sesuai dengan peruntukannya sehingga menggangu proses pengelolaan sistem tersebut.

Dari temuan di atas menggambarkan bahwa harus ada aturan yang mengatur tentang spesifikasi perangkat keras (haedware) sehingga kecepatan akses bisa membantu dalam implementasi e-government di Provinsi Banten.

\section{Pengembangan E-Government untuk}

Pelayanan Publik

Implementasi e-government untuk 
pelayanan publik berdasarkan Inpres No. 3

Tahun 2003 memerlukan beberapa strategi, antara lain membangun e-government secara sistematik melalui tahapan yang realistik dan sasaran yang terukur, sehingga mudah difahami dan diikuti oleh semua pihak. Berdasarkan Inpres No. 3 Tahun 2009, pengembangan dan implementasi e-government dapat dilaksanakan melalui 4 tahapan (sosiawan, 2008) yaitu :

Tahap 1 Merupakan tahap persiapan meliputi pembuatan situs informasi di setiap lembaga, penyiapan sumber daya manusia (SDM), penyiapan sarana akses misalnya jaringan internet.

Tahap 2 Merupakan tahap pematangan, meliputi pembuatan situs informasi publik interaktif, dan pembuatan antar muka keterhubungan dengan lembaga lain.

Tahap 3 Merupakan tahap pemantapan, meliputi pembuatan situs transaksi pelayanan publik, dan pembuatan interoperabilitas.

Tahap 4 Merupakan tahapan pemanfaatan, meliputi pembuatan aplikasi untuk pelayanan yang bersifat $\mathrm{G} 2 \mathrm{G}$ (Government to Government), G2B (Government to Busines) dan
G2C (Government to Citizen) yang terintegrasi. Sebagai obyek layanan, $\mathrm{G} 2 \mathrm{G}$ berorientasi layanan ke intra kelembagaan pemerintah daerah, G2B berorientasi layanan dikhususkan untuk kalangan bisnis dan dunia usaha, sedangkan G2C berorientasi layanan ditujukan untuk masyarakat umum

Implementasi e-government Pemerintah Provinsi Banten masih banyak yang harus di benahi jika mengacu pada amanat Inpres no. 3 tahun 2003. Sebagai salah satu yang menjadi parameter adalah sebagai mana telah digambarkan pada hasil temuan yang sudah tersaji pada pembahasan diatas. Oleh karena itu upaya perbaikan sistem informasi melalui website bantenprov.go.id harus lebih diutamakan pada penyajian konten-konten yang berkaitan dengan layanan unit kerja pemerintah Provinsi Banten yang di tampilkan pada website tersebut dan dapat diakses secara elektronik oleh penggunanya/masyarakat. Hal tersebut bisa terealisasi jika aplikasiaplikasi tersebut saling terhubung atau terintergrasi dengan semua unit di SKPD, maka akan menjadi sangat powerfull dalam pelaksanaan kegiatan administratif maupun layanan publik berbasis e-government selain 
itu harus ada dukungan regulasi berupa peraturan gubernur yang membahas secara operasional terkait pengelolaan dan pelaksanaan e-government dipemerintah Provinsi Banten.

Dalam mengatasi adanya kelemahan dalam pengelolaan e-government untuk pelayanan publik, diperlukan adanya sistem informasi terintegrasi atau Enterprise Integration (EI), sebagai konsep untuk membuat setiap aplikasi yang bekerja pada berbagai platform berbeda dapat bekerja sama, dan berhubungan guna menghasilkan suatu kesatuan fungsionalitas, sehingga memungkinkan untuk saling berbagi informasi di dalam lembaga/ unit maupun diluar lembaga/ unit. Sistem ini juga melibatkan berbagai pihak di dalam dalam pelaksanaannya, dengan mengakomodir hubungan antara G2G (Pemerintah dengan pemerintah), G2B (pemerintah dengan pelaku bisnis), G2N (pemerintah dengan masyarakat).

Untuk mengintegrasikan sistem informasi yang ada di Pemerintah Provinsi Banten dapat menggunakan pendekatan yang dipandang sebagai integrasi lapisan (layer) yang proses integrasinya dapat dilakukan sesuai arsitektur berikut (Juric, dkk, 2007).

1. Integrasi data. Integrasi ini memusatkan adanya perpindahan data pada antar aplikasi dengan tujuan membagi data yang sama kepada beberapa aplikasi yang berbeda. Integrasi pada level ini merupakan titik awal dari proses integrasi. Dari sudut pandang teknis, integrasi data relatif sederhana dan tidak memerlukan adanya perubahan aplikasi. Masalah yang muncul adalah adanya kompleksitas dan jumlah basis data.

2. Integrasi aplikasi. Integrasi pada level aplikasi menitikberatkan integrasi antara aplikasi yang ada diwebsite utama (bantenprov.go.id) dengan aplikasi-aplikasi teknis yang ada di unit kerja masing-masing (OPD).

3. Integrasi presentasi. Integrasi presentasi menghasilkan sistem terintegrasi yang menyediakan lapisan presentasi yang menyatu dimana pengguna akan dapat mengakses fungsionalitas dari sistem terintegrasi.

4. Integrasi B2B. Saat ini integrasi aplikasi dalam Pemerintah Povinsi Banten memerlukan banyak faktor sesuai dengan kebutuhan. Terdapat kebutuhan yang memungkinkan integrasi antar instansi yang sering diacu sebagai Business to Business 
(B2B) dimana syarat yang harus dipenuhi untuk B2B yang efisien adalah sebuah sistem informasi enterprise yang terintegrasi pada level proses bisnis.

5. Integrasi sistem pelaporan. Integrasi sistem pelaporan merupakan bagian yang sangat penting dalam proses integrasi. Sistem pelaporan ada pada setiap SKPD atau unit pelayanan, misalnya sistem pelaporan bidang kesehatan atau pendidikan yang mencakup data di Kabupaten/Kota.

\section{KESIMPULAN}

Implementasi e-government untuk pelayanan publik di Pemerintah Provinsi Banten menggunakan situs bantenprov.go.id masih banyak hal yang harus diperbaharui sesuai amanat Inpres no.3 tahun 2003. Salah satu adalah masih banyak aplikasi dan sistem informasi belum tersedia sebagai bentuk layanan yang baik kepada pengguna/ masyarakat hal ini demi menunjang kinerja pelayanan kepada masyarakat melalui situs bantenprov.go.id. karena dalam pelaksanaan e-government sekarang ini masih belum adanya integrasi data dan sistem informasi yang ditampilkan melalui website baantenprov.go.id dengan website yang ada di unit kerja lingkup pemerintah Provinsi
Banten, selain itu konsep penyajian informasi belum bisa dirasakan secara luas oleh masyarakat karena masih banyak konten yang tidak tersedia berkaitan layanan apa saja yang bisa diberikan oleh pemerintah Provinsi Banten melalui unit kerjanya. Oleh karena itu dalam pelaksanaannya perlu dukungan regulasi tentang pengelolaan dan pelaksanaan e-government, penyempurnaan aplikasi, penyeragaman perangkat keras baik yang menyangkut besaran bandwidht yang khusus digunakan untuk mendukung pelaksanaan e-government maupun spesifikasi hardware lainnya misalnya spesifikasi komputer, peningkatan pengelolaan sumber daya manusia (SDM) sehingga penanggung jawab pengelolaan dalam pelaksanaan e-government di setiap OPD bisa berjalan maksimal misalnya pegawai yang bertanggung jawab di bidang pengelolaan e-government tidak mudah dipindahtugaskan tanpa memenuhi persyaratan-persyaratan yang sudah ditentukan.

Untuk memandu dan memudahkan dalam pelaksanaan e-government maka dapat di identifikasi tahapan-tahapan pengembangan pelaksanaannya sehingga tidak ada tahapan yang terlewati dan pada akhirnya pelaksanaan e-government bisa berjalan secara efektif dan efisien. Selain itu 
harus ada upaya untuk mengintegrasikan antar komponen yang dibutuhkan baik menyangkut integrasi data, aplikasi, bahkan komunikasi sistem informasi dengan pihak entitas eksternalnya misalnya G2G (Government to Government), G2B (Government to Busines) dan G2C (Government to Citizen).

\section{DAFTAR PUSTAKA}

Dwiyanto, A. 2006. Mewujudkan Good Governance :MelaluiPelayanan Publik. Yogyakarta : Gadjah Mada University Press.

Harso Supangkat Suhono. 2006. framework strategi implementasi e-government. Prosiding Konferensi Nasional Teknologi Informasi \& Komunikasi untuk Indonesia

Arief Sosiawan Edwi. 2008. Tantangan dan Hambatan dalam Implementasi E-Government di Indonesia

Faizah, N. \& Sensuse D. I. 2009. FaktorFaktor Sukses Implementasi E-Government di Empat Kabupaten di Indonesia. Digital Information \& System Conference.

Darmawan Ikhsan. 2011. E-Government : Studi Pendahuluan di Kabupaten Sragen. Proceeding Simposium Nasional Otonomi Daerah Untirta

Fitriansyah, A., H. Budiarto, dan J. Santoso. 2013. Metode Pemeringkatan E-Government Indonesia (PEGI) Untuk Audit Tata
Kelola Teknologi Informasi. Seminar Nasional Sistem Informasi Indonesia. 24 Desember.

Junaidi. 2011. Dukungan E-Government dalam Upaya Peningkatan Kualitas Pelayanan Publik di Era Otonomi Daerah : Kasus Best Practices dari Sejumlah Daerah di Indonesia. Proceeding Simposium Nasioal Otonomi Daerah. Lab-ANE FISIP Untirta.

Raharjo, B. 2001. Membangun EGovernment. Bandung : ITB.

Sosiawan, E. A. 2008. Evaluasi Implementasi E-Government pada Situs Web Pemerintah Daerah di Indonesia: Perpektif Content dan Manajemen. http:/ /edw.dosen.upnyk.ac.id.

Utomo, S. D. 2008. Penanganan Pengaduan Masyarakat Mengenai Pelayanan Publik. Jurnal Ilmu Administrasi dan Organisasi, Bisnis dan Birokrasi. 15 (3). 
